\title{
ANALISIS SISTEM PERAWATAN MESIN BUBUT MENGGUNAKAN METODE RCM (RELIABILITY CENTERED MAINTENANCE) DI CV. JAYA PERKASA TEKNIK
}

\author{
Ilham Pramudya Raharja ${ }^{1)}$, Ida Bagus Suardika ${ }^{2)}$, Heksa Galuh W. ${ }^{3)}$ \\ ${ }^{1,2,3)}$ Program Studi Teknik Industri, Fakultas Teknologi Industri, Institut Teknologi Nasional Malang \\ Email : ilhampramudya08@gmail.com
}

\begin{abstract}
Abstrak, CV Jaya Perkasa Teknik merupakan salah satu jenis usaha dibidang industri mesin dan perlengkapan manufaktur yang memproduksi berbagai macam suku cadang dari beberapa mesin produksi. Mesin bubut yang digunakan sering mengalami kerusakan, sehingga menghambat jalannya proses produksi. Kerusakan mesin bubut terjadi dikarenakan terdapat komponen kritis yang menjadi penyebab terjadinya kerusakan. Pengecekan rutin dan perbaikan akibat kerusakan akan memerlukan biaya pemeliharaan yang cukup banyak. Perlu diterapkannya interval waktu pergantian optimum dan pemilihan tindakan perawatan komponen secara tepat yang diharapkan mampu mengurangi biaya pemeliharaan. Metode dalam penelitian ini adalah RCM (Reliability Centered Maintenance), yaitu melakukan analisa menggunakan pendekatan kualitatif dan kuantitatif, sehingga dapat menemukan akar penyebab kegagalan fungsi dan memberikan solusi yang tepat. Berdasarkan hasil analisis metode RCM ditentukan pemilihan tindakan perawatan terhadap komponen kritis mesin bubut, yaitu komponen Electric System, V-belt, Gear dan Bearing dengan tindakan perawatan TD (Time Directed). Interval waktu pergantian optimum komponen V-Belt 23 hari, Electric System 29 hari, Bearing 28 hari, dan Gear 31 hari. Berdasarkan perhitungan total biaya pemeliharaan diketahui terdapat penurunan dari total biaya pemeliharaan awal dengan total biaya pemeliharaan berdasarkan interval waktu pergantian optimum dari masing-masing komponen yaitu V-belt sebesar 1,31\%, Electric System sebesar 21,66\%, Bearing sebesar 24,67\%, dan Gear sebesar $31,89 \%$.
\end{abstract}

Kata kunci : Mesin Bubut, FMEA, Reliability Centered Maintenance, Interval Waktu Pergantian Optimum

\section{PENDAHULUAN}

Industri manufaktur di Indonesia mulai menunjukkan kebangkitannya di tengah pandemi pada bulan Juni 2020. Hal ini didukung dengan adanya aturan new normal yang diterapkan pemerintah (Kementrian Perindustrian, 2020). Era new normal saat ini menjadi waktu yang tepat bagi pemerintah untuk terus memacu perusahaan manufaktur untuk lebih berinovasi, sehingga mampu menghasilkan produk yang berkualitas dan berdaya saing global. Kemampuan perusahaan manufaktur dalam menghasilkan produk yang berkualitas tidak lepas dari peran penting industri mesin dan perlengkapan manufaktur yang menghasilkan mesin maupun peralatanperalatan manufaktur (Kementrian Perindustrian, 2016).

CV Jaya Perkasa Teknik merupakan salah satu jenis usaha dibidang industri mesin dan perlengkapan manufaktur yang memproduksi berbagai macam suku cadang dari berbagai macam mesin produksi. Masalah yang terdapat pada CV Jaya Perkasa Teknik, yaitu mesin yang digunakan sering mengalami kerusakan, sehingga menghambat jalannya proses produksi. Mesin yang paling sering mengalami kerusakan, yaitu mesin bubut. Mesin bubut adalah suatu mesin yang digunakan untuk membuat komponen suku cadang yang berbentuk benda silindris. Berikut data frekuensi kerusakan pada mesin bubut.

Tabel 1. Data Kerusakan Mesin Bubut Periode Juli 2019 - Juni 2020

\begin{tabular}{|c|c|l|}
\hline Periode & $\begin{array}{c}\text { Frekuensi } \\
\text { Kerusakan } \\
\text { (kali/x) }\end{array}$ & $\begin{array}{c}\text { Komponen Kritis } \\
\text { Penyebab Kerusakan }\end{array}$ \\
\hline Juli 2019 & 6 & $\begin{array}{l}\text { V-Belt, Electric System, } \\
\text { Bearing, Oil Gearbox, } \\
\text { Bolt \& Nut } \text { dan Gear }\end{array}$ \\
\hline $\begin{array}{c}\text { Agustus } \\
2019\end{array}$ & 5 & $\begin{array}{l}\text { V-Belt, Electric System } \\
\text { dan Oil Gearbox }\end{array}$ \\
\hline $\begin{array}{c}\text { September } \\
2019\end{array}$ & 2 & $\begin{array}{l}\text { Electric System } \text { dan } \text { V- } \\
\text { Belt }\end{array}$ \\
\hline $\begin{array}{c}\text { Oktober } \\
2019\end{array}$ & 5 & $\begin{array}{l}\text { Oil Gearbox, Bolt \& Nut, } \\
\text { Gear } \text { dan Bearing }\end{array}$ \\
\hline
\end{tabular}

(Sumber : CV Jaya Perkasa Teknik) 
Tabel 2. Data Kerusakan Mesin Bubut Periode Juli 2019 - Juni 2020 (Lanjutan)

\begin{tabular}{|c|c|c|}
\hline Periode & $\begin{array}{c}\text { Frekuensi } \\
\text { Kerusakan } \\
(\text { kali/x) } \\
\end{array}$ & $\begin{array}{c}\text { Komponen Kritis } \\
\text { Penyebab } \\
\text { Kerusakan } \\
\end{array}$ \\
\hline $\begin{array}{l}\text { November } \\
2019\end{array}$ & 3 & $\begin{array}{l}\text { Electric System } \\
\text { dan } V \text {-Belt }\end{array}$ \\
\hline $\begin{array}{l}\text { Desember } \\
2019\end{array}$ & 5 & $\begin{array}{l}\text { V-Belt, Electric } \\
\text { System, Bearing, } \\
\text { Bolt \& Nut dan } \\
\text { Gear }\end{array}$ \\
\hline $\begin{array}{c}\text { Januari } \\
2020\end{array}$ & 4 & $\begin{array}{l}\text { V-Belt, Bearing, } \\
\text { Oil Gearbox dan } \\
\text { Gear }\end{array}$ \\
\hline $\begin{array}{c}\text { Februari } \\
2020\end{array}$ & 2 & $\begin{array}{l}\text { V-Belt dan Oil } \\
\text { Gearbox }\end{array}$ \\
\hline $\begin{array}{c}\text { Maret } \\
2020\end{array}$ & 3 & $\begin{array}{l}\text { Bearing, Bolt \& } \\
\text { Nut dan Oil } \\
\text { Gearbox }\end{array}$ \\
\hline April 2020 & 1 & $\begin{array}{l}\text { Bearing, Electric } \\
\text { System dan Oil } \\
\text { Gearbox }\end{array}$ \\
\hline Mei 2020 & 1 & $\begin{array}{l}\text { Gear dan Oil } \\
\text { Gearbox }\end{array}$ \\
\hline Juni 2020 & 3 & $\begin{array}{l}\text { Electric System, } \\
\text { Bearing dan Oil } \\
\text { Gearbox }\end{array}$ \\
\hline Jumlah & 40 & \\
\hline
\end{tabular}

(Sumber : CV Jaya Perkasa Teknik)

Berdasarkan tabel 1 dan tabel 2, diketahui jumlah kerusakan mesin bubut pada periode Juli 2019 sampai Juni 2020 sebanyak 40 kali. Downtime pada mesin bubut terjadi dikarenakan terdapat beberapa komponen kritis yang sering mangalami kerusakan. Perusahaan telah melakukan pemeliharaan rutin untuk pengecekan pada seluruh mesin setiap 2 bulan sekali dan melakukan tindakan corrective untuk pergantian komponen saat terjadinya kerusakan yang diketahui akan memerlukan biaya pemeliharaan yang cukup banyak. Perlu diterapkannya interval waktu pergantian optimum dan pemilihan tindakan untuk perawatan komponen secara tepat yang diharapkan mampu mengurangi biaya pemeliharaan yang dikeluarkan oleh perusahaan.

Terdapat dua pendekatan yang biasa digunakan untuk merencanakan kegiatan perawatan mesin yaitu pendekatan RCM (Reliability Centered Maintenance) dan TPM (Total Productive Maintenance). Perbedaannya RCM melakukan pemeliharaan dengan mengkombinasikan praktek dan strategi dari preventive maintenance dan corrective maintenance untuk memaksimalkan umur dan fungsi peralatan dengan biaya yang minimal. Sementara TPM, melaksanakan sistem penerapan preventive maintenance yang komprehensif sepanjang umur alat, melibatkan semua karyawan dan mengembangkan preventive maintenance melalui 13 manajemen (Hamim, 2017). Penelitian ini menganalisis penentuan terhadap sistem perawatan dan interval waktu pergantian komponen yang dilakukan menggunakan metode Reliability Centered Maintenance.

\section{METODE}

Penelitian ini merupakan penelitian deskriptif dengan pendekatan kualitatif yaitu evaluasi kegagalan serta pemilihan tindakan perawatan secara tepat terhadap kerusakan komponen dan pendekatan kuantitatif yaitu perhitungan keandalan dan penentuan interval waktu pergantian yang optimum. Teknik pengumpulan data dilakukan dengan observasi dan wawancara terhadap karyawan produksi untuk mendapatkan data terkait objek penelitian.

\section{RCM (Reliability Centered Maintenance) \\ RCM (Reliability Centered} Maintenance) adalah suatu proses analisis yang digunakan untuk menentukan tindakan yang seharusnya dilakukan dalam menjamin suatu sistem agar dapat berjalan dengan baik dan sesuai fungsi yang diinginkan (Fani, 2019). Berdasarkan RCM-Gateway to World Class Maintenance dalam (Erwin, 2017). Langkah langkah yang diperlukan dalam proses RCM adalah sebagai berikut:

1. Pemilihan Sistem dan Pengumpulan Informasi

Proses RCM pada sistem yang akan dianalisis akan memperoleh informasi yang jelas dan detail tentang fungsi dan kegagalan fungsi komponen.

2. Pendefinisian Batasan Sistem

Langkah ini memerlukan definisi batas sistem yang lebih mendalam. Pendefinisian batas sistem ini bertujuan untuk menghindari tumpang tindih antara satu sistem dengan sistem lainnya.

3. Diagram Sistem dan Diagram Blok Fungsi

Dalam tahap ini terdapat tiga informasi yang harus dikembangkan, yaitu deskripsi 
sistem, blok diagram fungsi, dan system work breakdown structure (SWBS).

4. Fungsi Sistem dan Kegagalan Fungsi

Pada langkah ini, proses analisis dilakukan terhadap kegagalan fungsi, bukan kepada kegagalan peralatan karena kegagalan komponen akan dibahas lebih lanjut di tahapan berikutnya (FMEA). Biasanya kegagalan fungsi memiliki beberapa kondisi yang menyebabkan kegagalan.

5. FMEA (Failure Mode and Effect Analysis)

FMEA adalah metode yang bertujuan untuk menganalisis berbagai macam mode kegagalan dari sistem yang terdiri dari beberapa komponen dan menganalisis pengaruh terhadap fungsi sistem tersebut. Dalam FMEA juga dilakukan perhitungan nilai Risk Priority Number (RPN) yang mengukur resiko bersifat relatif. RPN diperoleh melalui hasil perkalian antara rating Severity, Occurrence dan Detection.

$\mathrm{RPN}=$ Severity $x$ Occurrence $x$ Detection

\section{LTA (Logic Tree Analysis)}

Penyusunan LTA bertujuan untuk menentukan prioritas pada tiap mode kerusakan dan melakukan tinjauan fungsi dan kegagalan fungsi, sehingga status mode kerusakan tidak sama. Analisis pada LTA menggolongkan setiap mode kerusakan kedalam empat kategori. Empat hal dalam analisis kekritisan adalah sebagai berikut:

a. Evident, yaitu apakah operator mengetahui dalam kondisi normal, telah terjadi gangguan dalam sistem?

b. Safety, yaitu apakah mode kegagalan menyebabkan masalah keselamatan?

c. Outage, yaitu apakah mode kerusakan mengakibatkan seluruh atau sebagaian mesin berhenti?

d. Category, yaitu pengkategorian setelah menjawab beberapa pertanyaan yang diajukan. Pada bagian ini komponen terbagi dalam 4 kategori, yaitu:

1. Kategori A (Safety problem), apabila kegagalan komponen mengakibatkan masalah keselamatan karyawan.

2. Kategori B (Outage problem), apabila kegagalan komponen mengakibatkan seluruh atau sebagian mesin berhenti.

3. Kategori C (Economic problem), apabila kegagalan komponen mengakibatkan masalah ekonomi perusahaan.

4. Kategori D (Hidden failure), apabila karyawan tidak mengetahui telah terjadinya kegagalan komponen dalam kondisi normal.

7. Pemilihan Tindakan

Proses ini akan menentukan tindakan yang tepat untuk setiap mode kerusakan tertentu. Tindakan perawatan terbagi menjadi 3 jenis, yaitu:

1. Condition Directed (C.D)

Tindakan yang bertujuan untuk mendeteksi kerusakan dengan dilakukan visual inspection, memeriksa alat, serta mengecek data yang ada. Apabila dalam pendeteksian ditemukan gejala-gejala kerusakan peralatan, maka dilakukan perbaikan atau penggantian komponen.

2. Time Directed (T.D)

Tindakan yang bertujuan untuk melakukan pencegahan langsung terhadap sumber kerusakan berdasar pada waktu atau umur komponen.

3. Finding Failure (F.F)

Tindakan yang bertujuan untuk menemukan kerusakan yang tidak terdeteksi dengan melakukan pengecekan secara berkala.

\section{Interval Penggantian Komponen Dengan Total Minimum Downtime}

Prinsip utama dalam manajemen perawatan adalah untuk menekan periode kerusakan hingga batas minimum, sehingga penggantian komponen berdasarkan downtime minimum menjadi sangat penting. Penentuan penggantian komponen yang dilakukan dengan meminimumkan downtime berdasarkan interval waktu penggantian:

Dimana:

$$
\begin{aligned}
& D(t)=\frac{H(t) T f+T p}{t+T P} \\
& H(t)=\int_{0}^{t} h(t) d t
\end{aligned}
$$

$$
\begin{aligned}
& \mathrm{H}(\mathrm{tp})=\text { Banyaknya kerusakan dalam interval } \\
& \text { waktu }(0, \text { tp) } \\
& \text { Tf = Waktu yang diperlukan untuk }
\end{aligned}
$$




\section{HASIL DAN PEMBAHASAN Pengumpulan Data}

Data yang dikumpulkan dalam penelitian ini adalah data komponen bubut yang sering mengalami kerusakan, data interval waktu kerusakan komponen mesin bubut, data waktu perbaikan komponen yang mengalami kerusakan dan Total Biaya Pemeliharaan Komponen periode Juli 2019 - Juni 2020. Berdasarkan observasi dan wawancara diperoleh data-data sebagai berikut:

Tabel 3. Data Interval Waktu Kerusakan Komponen Mesin Bubut periode Juli 2019 - Juni 2020

\begin{tabular}{|c|c|c|c|c|c|c|}
\hline \multirow{2}{*}{ No } & \multicolumn{7}{|c|}{ Interval Waktu Kerusakan (hari) } \\
\cline { 2 - 7 } & $\begin{array}{c}V- \\
\text { Belt }\end{array}$ & $\begin{array}{c}\text { Electric } \\
\text { System }\end{array}$ & $\begin{array}{c}\text { Bearin } \\
g\end{array}$ & $\begin{array}{c}\text { Oil } \\
\text { Gear } \\
\text { box }\end{array}$ & Gear & $\begin{array}{c}\text { Bolt } \\
\text { and } \\
\text { Nut }\end{array}$ \\
\hline 1 & 68 & 54 & 36 & 35 & 46 & 60 \\
\hline 2 & 41 & 48 & 39 & 41 & 41 & 59 \\
\hline 3 & 55 & 52 & 42 & 39 & 47 & 57 \\
\hline 4 & 64 & 39 & 52 & 45 & 51 & 53 \\
\hline 5 & 38 & 55 & 45 & 36 & 40 & 59 \\
\hline 6 & 36 & 47 & 39 & 38 & 50 & 63 \\
\hline 7 & 37 & 39 & 48 & 40 & 46 & \\
\hline 8 & & & 50 & & 39 & \\
\hline
\end{tabular}

(Sumber: CV Jaya Perkasa Teknik)

Tabel 3 menunjukkan data interval waktu kerusakan komponen mesin bubut yang sering mengalami kerusakan periode Juli 2019 sampai Juni 2020.

Tabel 4. Data Waktu Perbaikan Komponen (menit)

\begin{tabular}{|c|l|c|c|}
\hline No & Komponen & $\begin{array}{c}\text { Waktu } \\
\text { Perbaikan } \\
\text { Korektif } \\
\text { Komponen }\end{array}$ & $\begin{array}{c}\text { Waktu } \\
\text { Perbaikan } \\
\text { Preventif } \\
\text { Komponen }\end{array}$ \\
\hline 1 & V-Belt & 58 & 33 \\
\hline 2 & $\begin{array}{l}\text { Electric } \\
\text { System }\end{array}$ & 48 & 32 \\
\hline 3 & Bearing & 37 & 26 \\
\hline 4 & $\begin{array}{l}\text { Oil } \\
\text { Gearbox }\end{array}$ & 29 & 20 \\
\hline 5 & Gear & 64 & 41 \\
\hline 6 & $\begin{array}{l}\text { Bolt and } \\
\text { Nut }\end{array}$ & 32 & 24 \\
\hline
\end{tabular}

(Sumber : CV Jaya Perkasa Teknik) perbaikan atau penggantian komponen baik korektif saat terjadi kerusakan maupun preventif atau perbaikan dan pengecekan sebelum kerusakan selama periode Juli 2019 sampai Juni 2020.

Tabel 5. Total Biaya Pemeliharaan Awal Komponen Periode Juli 2019 - Juni 2020 (Rupiah)

\begin{tabular}{|c|l|c|c|c|}
\hline No & Komponen & $\begin{array}{c}\text { Biaya } \\
\text { Pemeliharaan } \\
\text { Rutin }\end{array}$ & $\begin{array}{c}\text { Biaya } \\
\text { Pemeliharaan } \\
\text { Korektif }\end{array}$ & Total \\
\hline 1 & V-Belt & 709.800 .000 & 828.590 .000 & 1.538 .390 .000 \\
\hline 2 & $\begin{array}{l}\text { Electric } \\
\text { System }\end{array}$ & 709.800 .000 & 830.200 .000 & 1.540 .000 .000 \\
\hline 3 & Bearing & 709.800 .000 & 948.712 .000 & 1.658 .512 .000 \\
\hline 4 & $\begin{array}{l}\text { Oil } \\
\text { Gearbox }\end{array}$ & 709.800 .000 & 828.450 .000 & 1.538 .250 .000 \\
\hline 5 & Gear & 709.800 .000 & 950.912 .000 & 1.660 .712 .000 \\
\hline 6 & $\begin{array}{l}\text { Bolt and } \\
\text { Nut }\end{array}$ & 709.800 .000 & 828.310 .000 & 1.538 .110 .000 \\
\hline
\end{tabular}

(Sumber : Pengolahan Data)

Tabel 5 menunjukkan total biaya awal pemeliharaan komponen dengan 2 bulan sekali pemeliharaan rutin dan tindakan korektif selama 1 tahun dari bulan Juli 2019 sampai bulan Juni 2020. Data yang diperoleh dilakukan analisis selanjutnya dengan tahapan RCM.

\section{Pemilihan Sistem}

Proses RCM pada sistem yang akan dianalisis akan memperoleh informasi yang jelas dan detil tentang fungsi dan kegagalan fungsi komponen. Dalam penelitian ini yang akan dianalisis, yaitu sistem pada mesin bubut. Mesin bubut merupakan suatu mesin yang digunakan untuk membuat komponen suku cadang yang berbentuk benda silindris.

\section{Pendefinisian Batasan Sistem}

Pendefinisian batasan sistem diperlukan agar terdapat batasan, sehingga komponen yang diidentifikasi menjadi jelas dan tidak tumpang tindih. Berdasarkan wawancara dan observasi komponen yang sering mengalami kerusakan pada mesin bubut, yaitu :
1. V-Belt
2. Electric System
3. Bearing
4. Oil Gearbox
5. Gear
6. Bolt and Nut

Tabel 4 menunjukkan data waktu perbaikan diambil dari rata-rata waktu 


\section{Deskripsi Sistem}

Pendeskripsian sistem dilakukan dengan SWBS (System Work Breakdown Structure). SWBS merupakan struktur yang menggambarkan sejumlah sistem dan sub sistem yang dapat mengakibatkan kegagalan dalam sebuah sistem kerja.

Tabel 6. System Work Breakdown Structure Mesin Bubut

\begin{tabular}{|c|c|c|c|c|}
\hline Sistem & Kode & $\begin{array}{c}\text { Sub } \\
\text { Sistem }\end{array}$ & Kode & Komponen \\
\hline \multirow{6}{*}{$\begin{array}{l}\text { Mesin } \\
\text { Bubut }\end{array}$} & \multirow{5}{*}{ A } & \multirow{5}{*}{$\begin{array}{c}\text { Kepala } \\
\text { Tetap }\end{array}$} & A.1 & $V$-Belt \\
\hline & & & A. 2 & $\begin{array}{l}\text { Electric } \\
\text { System }\end{array}$ \\
\hline & & & A. 3 & Bearing \\
\hline & & & A. 4 & $\begin{array}{c}\text { Oil } \\
\text { Gearbox }\end{array}$ \\
\hline & & & A. 5 & $\begin{array}{c}\text { Bolt and } \\
\text { Nut }\end{array}$ \\
\hline & B & Eretan & B.1 & Gear \\
\hline
\end{tabular}

(Sumber: Observasi Peneliti)

Keterangan pengkodean pada tabel 6 SWBS adalah Huruf A menandakan nama sub sistem dari mesin bubut yaitu kepala tetap dan Eretan, sedangkan untuk angka di belakang kode A tersebut, yaitu menandakan nama komponen dari masing - masing sub sistem tersebut.

\section{Fungsi Sistem dan Kegagalan Fungsi}

Penelusuran dan analisis data lebih mudah dilakukan dengan pengkodean fungsi dan kegagalan fungsi. Berikut pendeskripsian fungsi sistem dan kegagalan fungsi dari komponen mesin bubut yang disajikan dalam tabel 7.

Tabel 7. Fungsi Sistem dan Kegagalan Fungsi

\begin{tabular}{|c|c|c|c|c|}
\hline $\begin{array}{c}\text { Kode } \\
\text { Fung } \\
\text { si }\end{array}$ & $\begin{array}{c}\text { Kode } \\
\text { Deskrip } \\
\text { si } \\
\text { Fungsi }\end{array}$ & $\begin{array}{l}\text { Uraian } \\
\text { Fungsi }\end{array}$ & $\begin{array}{c}\text { Kode } \\
\text { Kegagal } \\
\text { an } \\
\text { Fungsi }\end{array}$ & $\begin{array}{c}\text { Kegagalan } \\
\text { Fungsi }\end{array}$ \\
\hline A & A. 1 & $\begin{array}{l}\text { Berfungsi } \\
\text { sebagai } \\
\text { penyambu } \\
\text { ng daya } \\
\text { dari motor } \\
\text { ke poros } \\
\text { melalui } \\
\text { pulley } \\
\text { mengikuti } \\
\text { laju } \\
\text { putaran } \\
\text { pada } \\
\text { gearbox }\end{array}$ & A.1.1 & $\begin{array}{l}\text { V-Belt } \\
\text { kendur, } \\
\text { pecah, dan } \\
\text { slip yang } \\
\text { berdampak } \\
\text { pada putaran } \\
\text { poros yang } \\
\text { tidak } \\
\text { maksimal } \\
\text { dan bisa } \\
\text { mengakibat } \\
\text { kan V-belt } \\
\text { putus }\end{array}$ \\
\hline
\end{tabular}

\begin{tabular}{|c|c|c|c|c|}
\hline & A. 2 & $\begin{array}{l}\text { Electric } \\
\text { Panel } \\
\text { untuk } \\
\text { motor } \\
\text { sebagai } \\
\text { penggerak } \\
\text { mesin }\end{array}$ & A. 2.1 & $\begin{array}{l}\text { Kontraktor } \\
\text { dan relay } \\
\text { yang rusak } \\
\text { disebabkan } \\
\text { oleh beban } \\
\text { arus listrik } \\
\text { dan plat } \\
\text { sudah } \\
\text { lemah/putus, } \\
\text { sehingga } \\
\text { berdampak } \\
\text { pada mesin } \\
\text { yang tidak } \\
\text { bisa } \\
\text { dinyalakan }\end{array}$ \\
\hline & A. 3 & $\begin{array}{l}\text { Berfungsi } \\
\text { sebagai } \\
\text { bantalan } \\
\text { tempat } \\
\text { berputarny } \\
\text { a poros, } \\
\text { sehingga } \\
\text { menjaga } \\
\text { perputaran } \\
\text { poros } \\
\text { tetap stabil }\end{array}$ & A.3.1 & $\begin{array}{l}\text { Bearing aus, } \\
\text { kondisi ini } \\
\text { dapat } \\
\text { mengakibat } \\
\text { kan } \\
\text { kerusakan } \\
\text { poros dan } \\
\text { perputaran } \\
\text { mesin } \\
\text { terganggu }\end{array}$ \\
\hline & A. 4 & $\begin{array}{l}\text { Berfungsi } \\
\text { sebagai } \\
\text { pelumas } \\
\text { pada } \\
\text { gearbox }\end{array}$ & A. 4.1 & $\begin{array}{l}\text { Kurangnya } \\
\text { pelumasan } \\
\text { yang dapat } \\
\text { mengakibat } \\
\text { kan gear } \\
\text { cepat panas }\end{array}$ \\
\hline & A. 5 & $\begin{array}{l}\text { Berfungsi } \\
\text { sebagai } \\
\text { sambunga } \\
\mathrm{n} \quad \text { antar } \\
\text { komponen }\end{array}$ & A. 5.1 & $\begin{array}{l}\text { Belt and Nut } \\
\text { kendur yang } \\
\text { mengakibat } \\
\text { kan } \\
\text { sambungan } \\
\text { antar } \\
\text { komponen } \\
\text { dapat } \\
\text { terlepas }\end{array}$ \\
\hline B & B. 1 & $\begin{array}{l}\text { Berfungsi } \\
\text { sebagai } \\
\text { roda } \\
\text { penggerak }\end{array}$ & B.1.1 & $\begin{array}{l}\text { Gear aus } \\
\text { mengakibat } \\
\text { kan putaran } \\
\text { mesin atau } \\
\text { laju di eretan } \\
\text { terganggu }\end{array}$ \\
\hline
\end{tabular}

(Sumber: CV Jaya Perkasa Teknik)

\section{Failure Mode and Effect Analysis}

FMEA adalah metode yang bertujuan untuk menganalisis berbagai macam mode kegagalan dari sistem yang terdiri dari beberapa komponen dan menganalisis pengaruh terhadap fungsi sistem tersebut. Nilai RPN menunjukkan tingkatan prioritas komponen yang dianggap beresiko tinggi. Berikut hasil analisis FMEA dan perhitungan nilai RPN: 
Tabel 8. Failure Mode and effect Analysis Komponen Mesin Bubut

\begin{tabular}{|c|c|c|c|c|c|c|c|c|}
\hline \multicolumn{9}{|c|}{ FMEA Worksheet } \\
\hline No & Part & Function & Failure Mode & Failure Effect & $\mathrm{S}$ & $\mathrm{O}$ & $\mathrm{D}$ & RPN \\
\hline 1 & $V$-Belt & $\begin{array}{l}\text { Sebagai penyambung daya } \\
\text { dari motor ke poros } \\
\text { melalui pulley mengikuti } \\
\text { laju putaran pada gearbox }\end{array}$ & $\begin{array}{l}V \text {-belt pecah } \\
\text { dan Kendur }\end{array}$ & $\begin{array}{l}\text { Putaran poros } \\
\text { yang tidak } \\
\text { maksimal dan } \\
\text { bisa } \\
\text { mengakibatkan } \\
V \text {-belt putus }\end{array}$ & 7 & 3 & 3 & 63 \\
\hline 2 & $\begin{array}{l}\text { Electric } \\
\text { System }\end{array}$ & $\begin{array}{l}\text { Electric Panel untuk motor } \\
\text { sebagai penggerak meisn }\end{array}$ & $\begin{array}{l}\text { Kontraktor dan } \\
\text { relay rusak }\end{array}$ & $\begin{array}{l}\text { Berdampak } \\
\text { pada mesin } \\
\text { yang tidak bisa } \\
\text { dinyalakan }\end{array}$ & 8 & 3 & 4 & 96 \\
\hline 3 & Bearing & $\begin{array}{l}\text { Sebagai bantalan tempat } \\
\text { berputarnya poros, } \\
\text { sehingga menjaga } \\
\text { perputaran poros tetap } \\
\text { stabil }\end{array}$ & Bearing aus & $\begin{array}{l}\text { Mengakibatkan } \\
\text { kerusakan } \\
\text { poros dan } \\
\text { putaran mesin } \\
\text { terganggu }\end{array}$ & 5 & 4 & 2 & 40 \\
\hline 4 & $\begin{array}{l}\text { Oil } \\
\text { Gearbox }\end{array}$ & $\begin{array}{l}\text { Berfungsi sebagai pelumas } \\
\text { pada gearbox }\end{array}$ & $\begin{array}{l}\text { Kurang } \\
\text { Pelumasan }\end{array}$ & $\begin{array}{l}\text { Dapat } \\
\text { mengakibatkan } \\
\text { gear cepat } \\
\text { panas }\end{array}$ & 4 & 3 & 2 & 24 \\
\hline 5 & $\begin{array}{l}\text { Bolt and } \\
\text { Nut }\end{array}$ & $\begin{array}{l}\text { Berfungsi sebagai } \\
\text { sambungan antar } \\
\text { komponen }\end{array}$ & $\begin{array}{l}\text { Bolt and Nut } \\
\text { kendur }\end{array}$ & $\begin{array}{l}\text { Mengakibatkan } \\
\text { sambungan } \\
\text { antar } \\
\text { komponen } \\
\text { dapat terlepas }\end{array}$ & 4 & 3 & 1 & 12 \\
\hline 6 & Gear & $\begin{array}{l}\text { Berfungsi sebagai roda } \\
\text { penggerak }\end{array}$ & Gear aus & $\begin{array}{l}\text { Mengakibatkan } \\
\text { putaran mesin } \\
\text { atau laju di } \\
\text { eretan } \\
\text { terganggu }\end{array}$ & 6 & 4 & 2 & 48 \\
\hline
\end{tabular}

(Sumber: Pengolahan Data)

Berdasarkan tabel 8 hasil dari FMEA diketahui nilai RPN yang paling tinggi hingga terendah yaitu komponen Electric System dengan RPN sebesar 96, V-belt dengan RPN sebesar 63, Gear dengan RPN sebesar 48, Bearing dengan $=$ RPN sebesar 40, Oil Gearbox dengan RPN sebesar 24, dan Bolt and Nut dengan RPN sebesar 12. Peneliti menentukan komponen kritis berdasarkan 4 nilai RPN tertinggi yaitu komponen Electric System, $V$ belt, Gear, dan bearing.

\section{Logic Tree Analysis}

Pada bagian kolom tabel LTA terdapat nomor dan nama kegagalan fungsi, mode kerusakan, dan analisis kekritisan. Empat hal dalam analisis kekritisan adalah sebagai berikut: a. Evident, yaitu apakah operator mengetahui dalam kondisi normal, telah terjadi gangguan dalam sistem?

b. Safety, yaitu apakah mode kegagalan menyebabkan masalah keselamatan?

c. Outage, yaitu apakah mode kerusakan mengakibatkan seluruh atau sebagaian mesin berhenti?

d. Category, yaitu pengkategorian setelah menjawab beberapa pertanyaan yang diajukan. Pada bagian ini komponen terbagi dalam 4 kategori, yaitu:

1. Kategori A (Safety problem), apabila kegagalan komponen mengakibatkan masalah keselamatan karyawan.

2. Kategori B (Outage problem), apabila kegagalan komponen mengakibatkan seluruh atau sebagian mesin berhenti. 
3. Kategori C (Economic problem), apabila kegagalan komponen mengakibatkan masalah ekonomi perusahaan.

4. Kategori D (Hidden failure), apabila karyawan tidak mengetahui telah terjadinya kegagalan komponen dalam kondisi normal.

Untuk rekapitulasi analisis LTA komponen selanjutnya disajikan dalam tabel 9 berikut:

Tabel 9. Penyusunan LTA Komponen Mesin Bubut

\begin{tabular}{|c|l|c|c|c|c|}
\hline No & Komponen & Evident & Safety & Outage & Category \\
\hline 1 & $\begin{array}{l}\text { Electric } \\
\text { System }\end{array}$ & $\mathrm{Y}$ & $\mathrm{T}$ & $\mathrm{Y}$ & $\mathrm{B}$ \\
\hline 2 & V-Belt & $\mathrm{Y}$ & $\mathrm{T}$ & $\mathrm{Y}$ & $\mathrm{B}$ \\
\hline 3 & Gear & $\mathrm{Y}$ & $\mathrm{T}$ & $\mathrm{Y}$ & $\mathrm{B}$ \\
\hline 4 & Bearing & $\mathrm{Y}$ & $\mathrm{T}$ & $\mathrm{Y}$ & $\mathrm{B}$ \\
\hline
\end{tabular}

(Sumber: Observasi Peneliti)
Keterangan:
Y: YA
T: TIDAK
B: Outage Problem

Berdasarkan tabel 9, hasil penyusunan LTA diketahui ada 4 komponen kritis yang termasuk dalam kategori B (Outage Problem) yaitu kegagalan komponen mengakibatkan seluruh atau sebagian mesin berhenti yaitu Electric System, V-belt, Gear dan Bearing.

\section{Pemilihan Tindakan}

Proses ini menentukan tindakan yang tepat untuk setiap mode kerusakan tertentu. Pemilihan tindakan didasari dengan menjawab pertanyaan penuntun (selection guide) yang disesuaikan pada road map. Rekapitulasi pemilihan tindakan dapat dilihat pada tabel 10 sebagai berikut :

Tabel 10. Hasil Pemilihan Tindakan

\begin{tabular}{|c|c|c|c|c|c|c|c|c|c|c|}
\hline \multirow{2}{*}{ No } & \multirow{2}{*}{ Komponen } & \multirow{2}{*}{ Failure Mode } & \multicolumn{7}{|c|}{ Selection Guide } & \multirow{2}{*}{$\begin{array}{l}\text { Selection } \\
\text { Task }\end{array}$} \\
\hline & & & 1 & 2 & 3 & 4 & 5 & 6 & 7 & \\
\hline 1 & $\begin{array}{l}\text { Electric } \\
\text { System }\end{array}$ & $\begin{array}{l}\text { Kontraktor dan } \\
\text { relay rusak }\end{array}$ & $\mathrm{Y}$ & $\mathrm{Y}$ & $\mathrm{T}$ & $\mathrm{T}$ & & $\mathrm{Y}$ & - & TD \\
\hline 2 & V-Belt & $\begin{array}{l}V \text {-belt pecah dan } \\
\text { kendur }\end{array}$ & $\mathrm{Y}$ & $\mathrm{Y}$ & $\mathrm{T}$ & $\mathrm{T}$ & & $\mathrm{Y}$ & & $\mathrm{TD}$ \\
\hline 3 & Gear & Gear aus & $\mathrm{Y}$ & $\mathrm{Y}$ & $\mathrm{T}$ & $\mathrm{T}$ & - & Y & - & TD \\
\hline 4 & Bearing & Bearing aus & $\mathrm{Y}$ & Y & $\mathrm{T}$ & $\mathrm{T}$ & - & Y & - & TD \\
\hline
\end{tabular}

(Sumber : Observasi Peneliti)

Keterangan:

$$
\begin{array}{ll}
\text { Y } & : \text { YA } \\
\mathrm{T} & : \text { TIDAK } \\
\mathrm{TD} & : \text { Time Directed }
\end{array}
$$

Berdasarkan tabel 10, pemilihan tindakan pada komponen kritis mesin bubut diantaranya komponen Electric System, V-Belt, Gear dan Bearing adalah tindakan Time Directed yaitu tindakan yang bertujuan untuk melakukan pencegahan langsung terhadap kerusakan berdasar pada waktu atau umur komponen.

\section{Pengujian Pola Distribusi dan Penentuan Parameter}

Berdasarkan hasil yang diperoleh dari analisis RCM pada mesin bubut, maka komponen yang akan diuji pola distribusinya dan kemudian ditentukan nilai reliability adalah pemilihan tindakan perawatan berdasarkan waktu atau Time Directed (TD). Komponen tersebut adalah Electric System, V-belt, Gear dan Bearing. Adapun data yang digunakan yaitu interval waktu kerusakan dari komponen tersebut.

Pengujian distribusi interval waktu kerusakan komponen dengan uji goodness of fit (kesesuaian) pada pola distribusi yang lazim digunakan dalam reliability, yaitu distribusi weibull, normal, lognormal, dan eksponensial menggunakan software Minitab. Berikut rekapitulasi hasil pengujian distribusi dan penentuan parameter dari komponen dengan tindakan TD: 
Tabel 11. Hasil Pengujian Distribusi dan Penentuan Parameter (Hari)

\begin{tabular}{|c|l|c|c|}
\hline No & Komponen & $\begin{array}{c}\text { Pola } \\
\text { Distribusi }\end{array}$ & Parameter \\
\hline 1 & $\begin{array}{l}\text { Electric } \\
\text { System }\end{array}$ & Normal & $\begin{array}{c}\mu=47,4286 \\
\sigma=7,22072\end{array}$ \\
\hline 2 & V-belt & Lognormal & $\begin{array}{c}\mu=3,84733 \\
\sigma=0,286162\end{array}$ \\
\hline 3 & Gear & Normal & $\begin{array}{c}\mu=45 \\
\sigma=4,87115\end{array}$ \\
\hline 4 & Bearing & Normal & $\begin{array}{c}\mu=43,875 \\
\sigma=6,31362\end{array}$ \\
\hline
\end{tabular}

(Sumber: Pengolahan Data)

Keterangan:

$\mu=$ Rata - Rata

$\sigma=$ Standar Deviasi

Berdasarkan hasil pengujian diketahui distribusi terpilih adalah seperti pada tabel 11, dimana pemilihan distribusi berdasarkan dengan nilai anderson-darling (adj) terkecil dan koefisien korelasi terbesar.

\section{Perhitungan Interval Waktu Pergantian} Optimum Dengan Total Minimum Downtime

Pendekatan total minimum downtime adalah untuk menekan periode kerusakan hingga batas minimum dalam menentukan keputusan interval pergantian komponen. Data waktu perbaikan dapat dilihat pada tabel 4 .

Tabel 12. Interval Pergantian Optimum (Hari)

\begin{tabular}{|c|l|c|}
\hline No & Komponen & $\begin{array}{c}\text { Interval } \\
\text { Pergantian } \\
\text { Optimum }\end{array}$ \\
\hline 1. & Electric System & 29 \\
\hline 2. & V-belt & 23 \\
\hline 3. & Gear & 31 \\
\hline 4. & Bearing & 28 \\
\hline
\end{tabular}

(Sumber : Pengolahan Data)

Berdasarkan tabel 12, perhitungan dengan total minimum downtime didapatkan hasil interval pergantian yang optimum dari masing - masing komponen kritis yaitu komponen V-Belt 23 hari, Electric System 29 hari, Bearing 28 hari, dan Gear 31 hari.

\section{Perhitungan Biaya Pemeliharaan Komponen}

Berikut rekapitulasi selisih biaya pemeliharaan awal dengan biaya pemeliharaan interval waktu pergantian optimum untuk masing-masing komponen selama setahun:

Tabel 13. Presentase Penurunan Biaya Pemeliharaan Komponen

\begin{tabular}{|c|l|c|c|c|c|}
\hline No & Komponen & $\begin{array}{c}\text { Biaya } \\
\text { Pemeliharaan } \\
\text { Awal (Rp) }\end{array}$ & $\begin{array}{c}\text { Biaya Pemeliharaan dengan } \\
\text { Interval Waktu Pergantian } \\
\text { Optimum (Rp) }\end{array}$ & $\begin{array}{c}\text { Selisih Biaya } \\
\text { (Rp) }\end{array}$ & $\begin{array}{c}\text { Presentase } \\
\text { Penurunan } \\
\text { Biaya (\%) }\end{array}$ \\
\hline 1 & Electric System & 1.540 .000 .000 & 1.186 .000 .000 & 354.000 .000 & 22,99 \\
\hline 2 & V-Belt & 1.538 .390 .000 & 1.518 .223 .913 & 20.166 .087 & 1,31 \\
\hline 3 & Gear & 1.660 .712 .000 & 1.131 .125 .161 & 529.586 .839 & 31,89 \\
\hline 4 & Bearing & 1.658 .512 .000 & 1.249 .419 .821 & 409.092 .179 & 24,67 \\
\hline
\end{tabular}

Berdasarkan tabel 13, diketahui selisih dari total biaya pemeliharaan awal dengan total biaya pemeliharaan interval waktu pergantian optimum untuk masing-masing komponen. Komponen dengan penurunan biaya yang paling tinggi yaitu komponen gear dengan selisih sebesar $31,89 \%$.

\section{KESIMPULAN DAN SARAN Kesimpulan}

Kesimpulan yang dapat diambil dalam penelitian ini adalah:
1. Metode RCM yang digunakan dalam penilitian ini merupakan suatu proses analisis yang melakukan pemeliharaan dengan mengkombinasikan praktek dan strategi dari preventive maintenance dan corrective maintenance. Proses analisis dilakukan dengan pendekatan kualitatif maupun kuantitatif, sehingga dapat diketahui penyebab kerusakan dan tindakan perawatan secara tepat untuk memaksimalkan umur serta fungsi peralatan dengan biaya yang minimal. Berdasarkan 
analisis yang dilakukan didapatkan hasil pendeskripsian kegagalan fungsi dan analisis FMEA (Failure Mode and Effect Analysis) dengan perhitungan nilai RPN yaitu terdapat komponen kritis penyebab terjadinya kerusakan mesin bubut. Komponen tersebut adalah komponen Electric System dengan RPN sebesar 96, VBelt dengan RPN sebesar 63, Gear dengan RPN sebesar 48, dan Bearing dengan RPN sebesar 40.

2. Berdasarkan hasil analisis metode RCM ditentukan hasil pemilihan tindakan perawatan terhadap komponen kritis mesin bubut yaitu komponen Electric System, Vbelt, Gear dan Gear dengan tindakan perawatan TD (Time Directed) yang melakukan pencegahan langsung terhadap kerusakan yang didasarkan pada waktu. Tindakan pemeliharaan dengan pencegahan langsung dapat dilakukan dengan melakukan pergantian komponen secara berkala atau dengan interval waktu pergantian yang optimum dengan pendekatan total minimum downtime yang paling kecil, sehingga dapat meminimalisir terjadinya kerusakan. Berdasarkan hasil perhitungan didapatkan interval waktu pergantian yang optimum untuk komponen $V$-Belt dengan interval waktu pergantian 23 hari, Electric System 29 hari, Bearing 28 hari, dan Gear 31 hari.

3. Berdasarkan perhitungan total biaya pemeliharaan diketahui terdapat penurunan dari total biaya pemeliharan awal dengan total biaya pemeliharaan berdasarkan interval waktu pergantian optimum dari masing-masing komponen yaitu Electric System sebesar Rp.354.000.000 atau 21,66\%, V-belt sebesar Rp.20.166.087 atau 1,31\%, Gear sebesar Rp.529.586.839 atau $31,89 \%$ dan Bearing sebesar Rp.409.092.179 atau 24,67\%.

\section{Saran}

Saran yang diberikan dalam penelitian ini adalah:

1. Perusahaan diharapkan mendata secara lengkap terkait kerusakan maupun kegagalan fungsi dari komponen mesin bubut, sehingga dapat dengan mudah mendeteksi untuk komponen kritis.

2. Perusahaan diharapkan dapat menentukan dan menerapkan sistem preventive maintenance dengan jadwal dan waktu secara tepat agar dapat mengurangi waktu downtime dari mesin-mesin yang digunakan.

\section{DAFTAR PUSTAKA}

Agus S. Analisis Perawatan Mesin Bubut CYL1640g Dengan Metode Reliability Centered Maintenance (RCM) di PT Polymindo Permata. JITMI, Vol. 2 No. 1, ISSN : 2620-5793. Fakultas Teknik, Prodi Teknik Industri, Universitas Pamulang.

Agustinus D. S. dan Hery H. A. 2018. Perencanaan Perawatan Pada Unit Kompresor Tipe Screw Dengan Metode RCM Di Industri Otomotif. Jurnal Ilmiah Teknik Industri, ISSN: 1412-6869. Fakultas Teknik, President University, Bekasi.

Andina N. S., Ambar H., dan Fifi H. M. 2014. Usulan Kebijakan Perawatan Lokomotif Jenis CC201 Dengan Menggunakan Metode Reliability Centered Maintenance Di PT. Kereta Api Indonesia DIPO Bandung. Reka Integra, ISSN: 2338-5081. Jurusan Teknik Industri, Institut Teknologi Nasional (ITENAS), Bandung.

Cahyono Purnomo P. Evaluasi Manajemen Perawatan Dengan Metode Reliability Centered Maintenance (RCM) II Pada Mesin Cane Cutter 1 dan 2 Di Stasiun Gilingan PG Meritjan Kediri. Jurnal Ilmiah Rekayasa, Vol. 10 No. 2, ISSN: 2502-5325. Universitas Kahuripan, Kediri.

Erwin N. 2017. Penerapan Metode Reliability Centered Maintenance Menggunakan Software SPSS Pada Sistem Pendingin Generator Mitsubishi Kapasitas 62500 kVA (Studi Kasus Di PT. Toba Pulp Lestari, Tbk). Fakultas Teknik, Universitas Sumatera Utara, Medan.

Fani W. R. 2016. Implementasi Reliability Centered Maintenance (RCM) Pada Proses Gas Kriogenik. Fakultas Teknologi Industri, Institut Teknologi Sepuluh Nopember, Surabaya.

Farisa I., Sugiono, dan Remba Yanuar E. Implementasi Teknik Keandalan Untuk Mengoptimalkan Interval Perawatan Pada Sistem Coal Feeder (Studi Kasus: PT. PJB UP Paiton). Program Studi 
Teknik Industri, Fakultas Teknik, Universitas Brawijaya.

Hamim R. 2017. Usulan Perawatan Sistem Boiler Dengan Metode Reliability Centered Maintenance (RCM) (PT Indo Pusaka Berau). Fakultas Teknik, Universitas Muhammadiyah, Malang.

M. Arizki Z. R. 2018. Penentuan Interval Waktu Preventive Maintenance Pada Nail Making Machine Dengan Menggunakan Metode Reliability Centered Maintenance (RCM) Ii (Studi Kasus : PT Surabaya Wire). Fakultas Teknik, Universitas Muhammadiyah, Sidoarjo.

Noor A., dan Nur Yulianti H. 2017. Analisis Pemeliharaan Mesin Blowmould Dengan Metode RCM Di PT CCAI. Jurnal Optimasi Sistem Industri, ISSN: 2442-8795. Fakultas Teknik, Universitas Pancasila, Jakarta Selatan.

Oka Rambuna. 2019. Penerapan Metode Reliability Centered Maintenance (RCM) Pada Mesin Produksi Obat-
Obatan. Fakultas Teknologi Industi, Institut Teknologi Nasional, Malang.

Rizky W., Arumsari H., dan Rizki T. 2016. Penentuan Interval Perawatan Dengan Menggunakan Model Age Replacement DI PT. " $X$ ". Seminar Nasional Mesin dan Industri (SNMI X). Teknik Industi, Fakultas Teknik, Universitas Pasundan, Bandung.

Taufik dan Selly Septyani. Penentuan Interval Waktu Perawatan Komponen Kritis Pada Mesin Turbin Di PT PLN (PERSERO) Sektor Pembangkit Ombilin. Jurnal Optimasi Sistem Industri, Vol. 14 No. 2, ISSN:2088-4842. Jurusan Teknik Industri, Fakultas Teknik, Universitas Andalas, Padang.

Yanuar Yuda P. 2015. Penentuan Interval Waktu Pergantian Komponen Kritis Pada Mesin Volpack Menggunakan Metode Age Replacement. Jurnal Teknik Industri, Vol. 16 No. 2, 2 Agustus 2015, ISSN: 2527-4112. Jurusan Teknik Industri, Fakultas Teknik, Universitas Muhammadiyah, Malang. 